\section{Om kimærer, mosaikker og hermafroditer}

af lic.scient., biolog, seniorforsker Anne Phaff Ussing, Det Kongelige Bibliotek

I disse tider med transplantationer, genmanipulation, kloning og andre kunstgreb kan der være behov for at forklare, hvordan individer, der er sammensmeltet af væv med forskellig genetisk sammensætning, er opstået, og hvilken konsekvens det har på deres udseende og livsfunktioner.

\section{Kimærer}

T ndivider, som har forskellig sammensætning af arvematerialet $i$ forskellige dele af kroppen, kaldes kimærer. Ordet stammer fra græsk: Xipaı $\alpha$ (Chímaira), et fabeldyr med hoved som en løve, krop som en ged, og hale som en slange. Det samme ord findes på latin: Chimaera.

Men kimærer er ikke bare fabeldyr, de findes også i den virkelige verden; somme tider er de resultatet af transplantationer eller blodtransfusioner, andre gange har de en naturlig forklaring.

I 2008 blev der født en ægte "trefarvet" hest. Eller rettere sagt, en ægte tofarvet, for hvid er jo ikke en

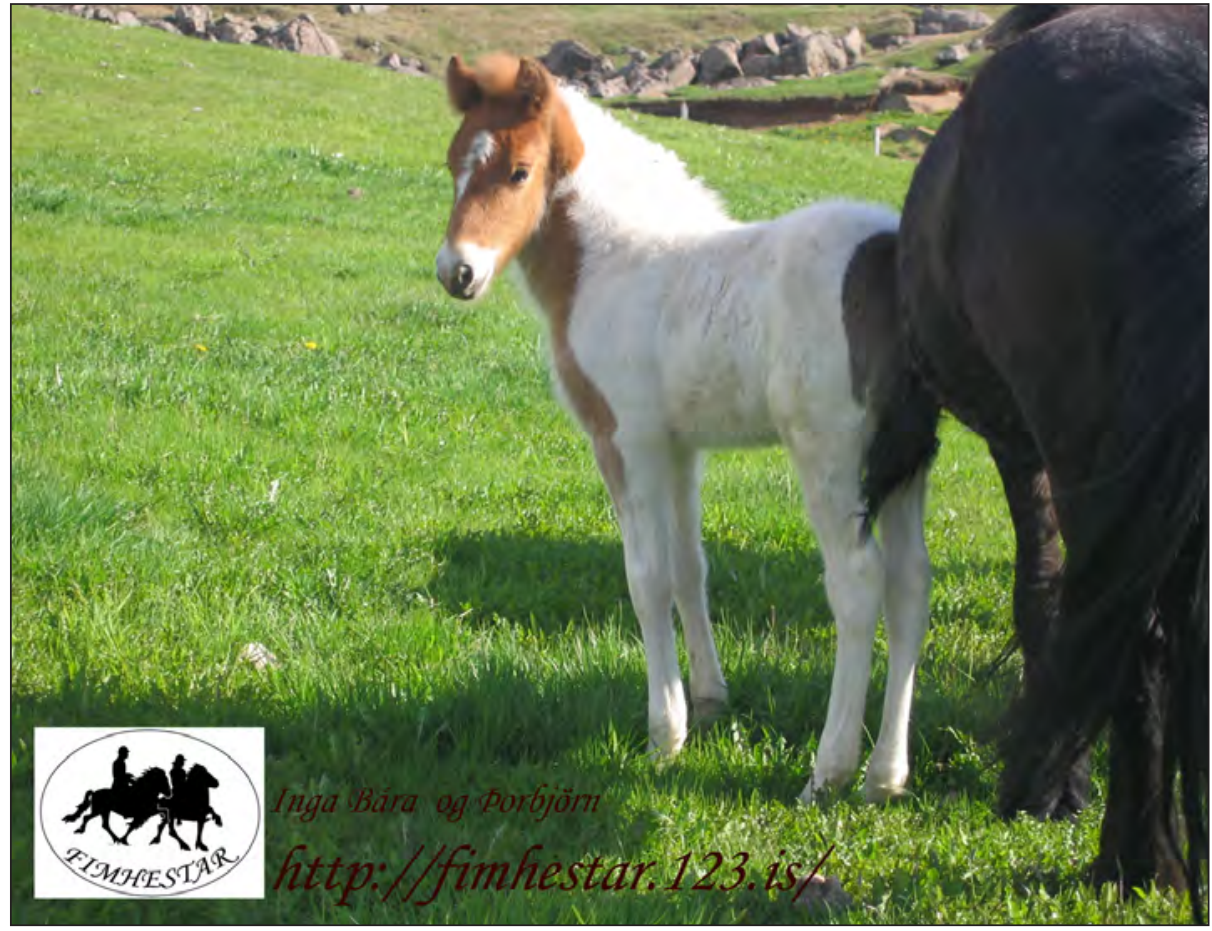

Follets fanotype er "trefarvet", og består formentlig af to forskellige genotyper. En agte kimare? (C) Inga Bára Ragnarsdottir). 


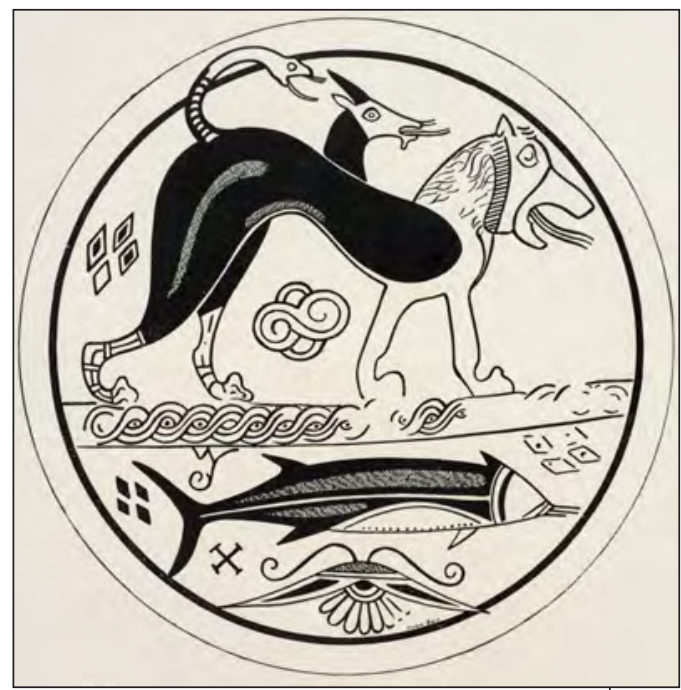

Kimare og delfin, fra Jean Anker og Svend Dabl, Fabeldyr og andre fabelvæsener, 1938.

farve. Det smukke føl på billedet er fænotypisk tobianobroget, med rødt pigment på forparten og sort pigment på bagparten. Fænotypen er det, man kan se. Genotypen er arveanlæggene bagved fænotypen. I dette tilfælde ser det ud til, at føllet er sammensat af to forskellige genotyper.

Der kan være flere videnskabelige forklaringer på ægte, naturligt opståede kimærer.

Den mest sandsynlige er, at ægget er blevet befrugtet af to sædceller. Fænomenet er set før, men optræder meget sjældent, idet det kræver, at sædcellerne når frem til ægcellens membran præcis samtidig med deres "næser". For så snart den ene sædcelle er begyndt at bore sig ind i ægget, bliver overfladen "lukket" for andre sædceller.

En anden forklaring kunne være to sammensmeltede ægceller. Dette er dog meget usandsynligt hos hesten, hvor der kun yderst sjældent modnes to æegceller samtidig. Det kan ses af, at hestetvillinger er meget sjældne. Men hos andre arter, såsom får, kunne denne mulighed have større betydning.

\section{Mosaikker}

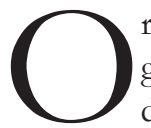
rdet mosaik har sine rødder fra græsk, Mousa (muse). På middelalderlatin findes musaicum, en af genitivformerne af Musa, i betydningen "af eller fra muserne". Senere afledtes mosaiko på latin og mosaique på fransk, $i$ betydningen et kunstværk $i$ form af et vindue eller en rude, som er sammensat af felter af glas i forskellige farver.

\section{I biologien kan mosaikker} forekomme, når der optræder en mutation i nogle, men ikke alle, celler i et individ. Mutationen kaldes somatisk, når den er opstået i en enkelt af individets kropsceller, og ikke nedarves til afkommet. Hvis mutationen derimod er sket $i$ forbindelse med dannelse af kønsceller (æg- og sædceller), vil den nedarves til afkommet. 


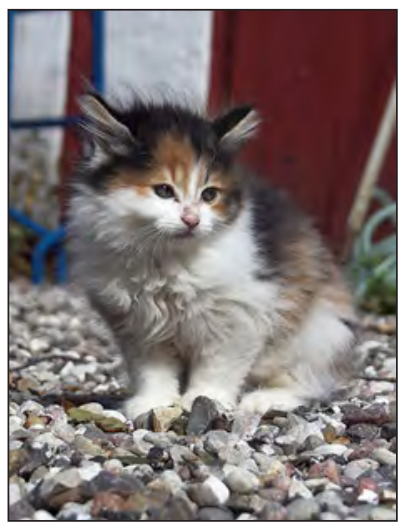

Den "trefar-

vede" kat er en

X-kromosom-

mosaik. De to

X-kromosomer

skiftes til at

bestemme $i$

de forskelligt

pigmenterede

partier. Det,

at der mangler

pigment nogle steder på krop-

pen, fär de

pigmenterede

omräder til at brede sig, så de forskelligt farvede omräder bliver storre og mere velafgransede. (C) Lis Milo Diemer).

\section{Arvelig mutation}

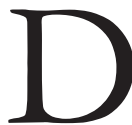
en mest kendte form for mosaik, som skyldes en mutation hos den ene af forældrene, er den trefarvede kat. Ligesom hos ovennævnte føl er der ikke tale om tre farver, men om to farver, samt upigmenterede, altså hvide områder.

Både den "trefarvede" og den "skildpaddemønstrede" (engelsk: tortoiseshell) kat har en mutation på det ene X-kromosom. Mutationen ændrer det sorte pigment til gult (som ser rødt ud når det er koncentreret). Det var længe en gåde, hvorfor de allerfleste af disse flerfarvede katte var hunner, og man bl.a. af denne årsag ikke var i stand til et "renavle" farvetypen. Når der en sjælden gang fandtes en hankat med et af disse farvemønstre, var den steril og kunne dermed ikke bruges i avlen.

Årsagen til denne kønsforskel skal findes i kønskromosomerne. Hos pattedyr har hunner to X-kromosomer, mens hanner har et X-kromosom og et Y-kromosom. På visse kattes X-kromosom findes en mutation, som ændrer det sorte pigment til gult. Hunner, som har arvet denne mutation fra den ene af forældrene, har derfor et "mosaik"-mønster af skiftevis sort og gult pigment. Sådanne hunners hankillinger vil være enten sorte eller røde, mens hunkillinger kan være enten sorte, røde eller mosaikmønstrede. Er der desu-

Den "skilpaddemonstrede" kat er en X-kromosom-mosaik, men uden de bvide (upigmenterede) områder. Når der ikeke er upigmenterede omräder, bliver de forskelligt farvede områder mindre, og blander sig mere ind $i$ binanden. (C) Lis Milo Diemer).

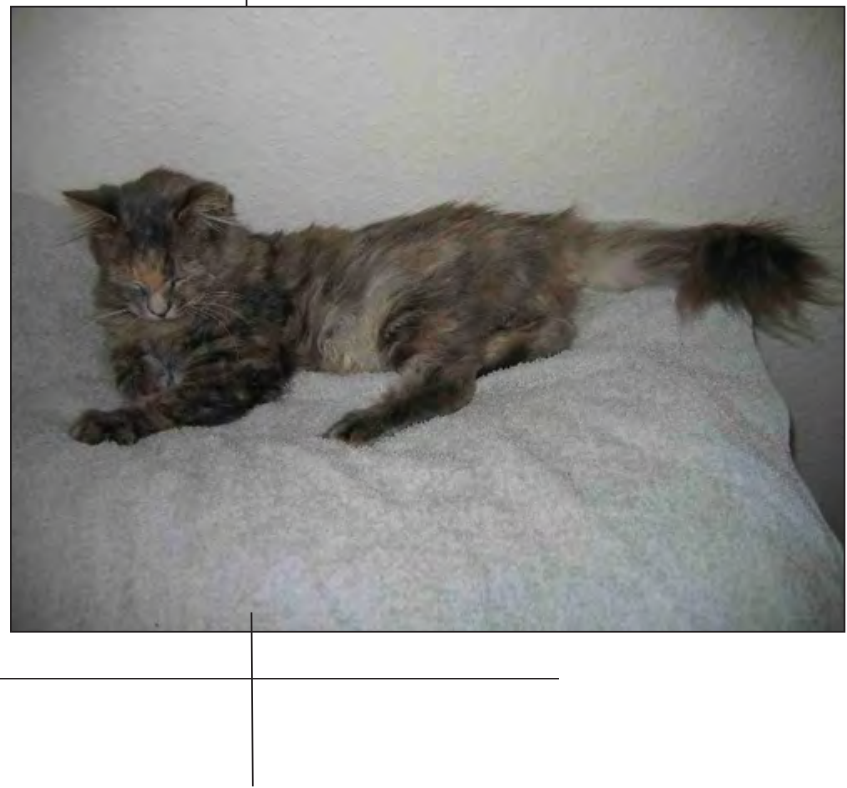




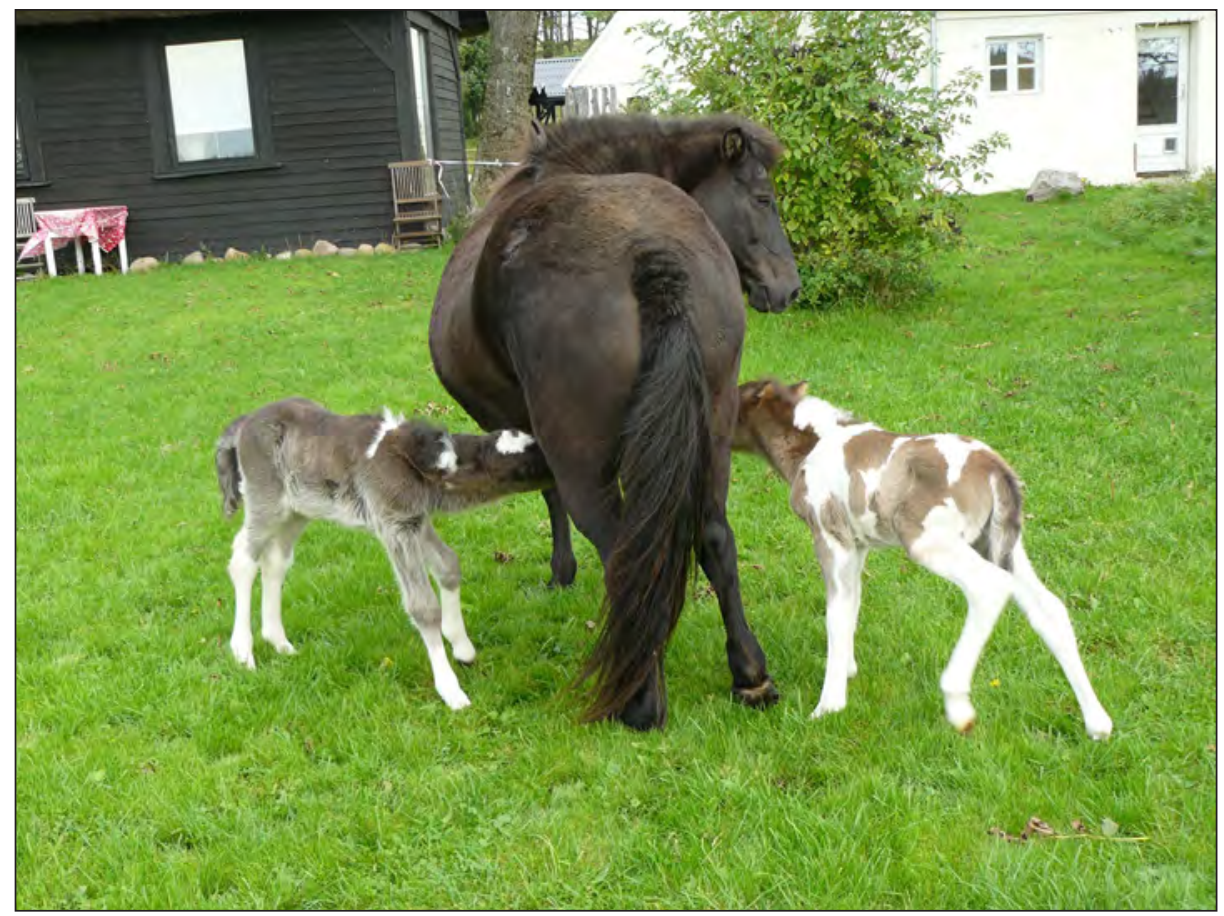

Tvillingefollene har arvet anlagget for broget lod (dvs. hvide omräder) fra deres fader. Forskellen $i$ de upigmenterede omraders storrelse og udformning er forarsaget af fanotypisk variation. Det er almindeligt, at de upigmenterede områder "fortranger" den rode farve mere end den sorte farve. De to fol har heller ikeke éns farvetegning pa begge sider. (C) Rie Dunvad).

den hvidt på katten, indgår det som en ekstra dimension, dog ikke som led i de små mosiakfelter, men koncentreret på bugsiden, samt $i$ ansigtet $o g$ på poterne. Når katten har upigmenterede ventrale områder, kompenserer de pigmenterede celler ved at udbrede sig mere end de ellers ville have gjort, således at de røde og sorte mosaikfelter på den "trefarvede" kat er større, end de er på den skildpaddemønstrede kat. Pigment er ikke bare pynt, det er både et styrkeelement i vævene og et kemisk aktivt molekyle, der fungerer som antioxidant og herved beskytter mod bl.a. sollysets ultraviolette stråler.

\section{Somatisk mutation}

Tandre tilfælde, hvor der kun er mindre områder med afvigende farve, er der formentlig tale om somatisk mutation, altså ændringer i arvematerialet (generne) som er opstået i en enkelt celle, efter at fosterudviklingen er begyndt. Det kan skyldes ydre påvirkninger, såsom bestråling eller kemiske påvirkning fra stoffer med teratogen (fosterskadende)virkning. Der kan også være tale om, at den genetiske "opskrift" ved en fejltagelse ikke er blevet fulgt, dengang pigmentet $i$ de pågældende områder blev dannet. I disse tilfælde er der tale om en mosaik, ikke en kimære, 
eftersom alle cellerne som udgangspunkt havde samme arvemateriale. De har altså ikke forskellig genetisk oprindelse, som de forskellige cellepopulationer i en kimære har det. DNA-analyser af arvematerialet kan belyse forholdene nærmere i det enkelte tilfælde; hertil behøves et antal hår, trukket ud med hårsækken på, fra hvert af områderne.

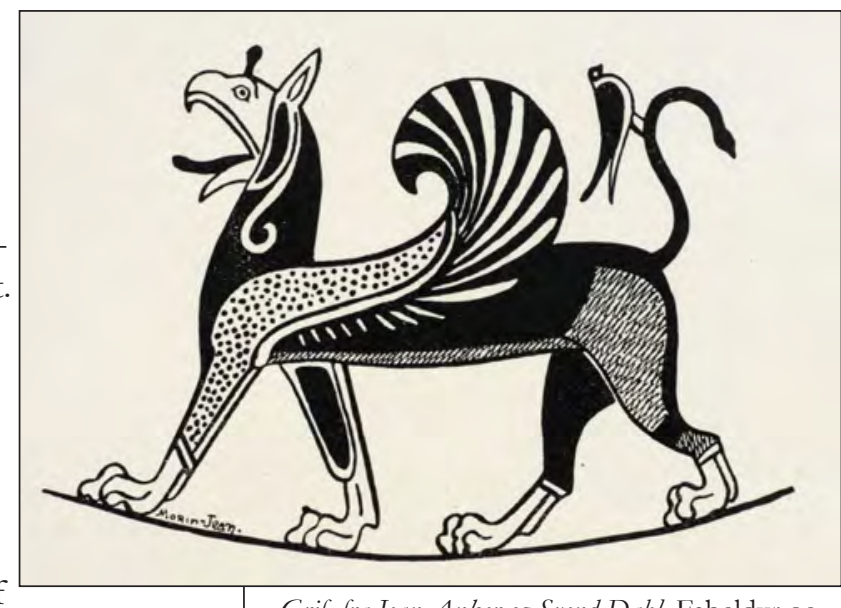

\section{Hermafroditter}

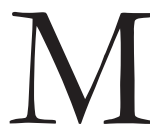
ens tvillinger er yderst sjældne hos heste, forekommer de mere hyppigt hos kvæg. Kalvetvillinger af hver sit køn har vist sig at have et udviklingsforløb, hvor kviekalvens kønsorganer ikke udvikles normalt, fordi den tidligt i fosterstadiet er påvirket af kønshormoner fra sin tvillingebroder, tyrekalven. Kviekalve, der har en tyrekalv som tvilling, fødes derfor som helt eller delvis hermafroditter, altså med både hanligt og hunligt kønspræg. Sådanne kvier kan ikke blive drægtige, og hermed heller ikke give mælk. Tidlige slagtede man dem som kalve, men nu er der nogle landmænd, der opfodrer dem som kødkvæg.

Den samme påvirkning sker ikke hos mennesketvillinger, og heller ikke hos hunde, katte osv., fordi moderkagen (placenta) her har en anderledes udformning, hvor blodkredsløbet ikke deles.

De tveæggede kalvetvillinger
Grif, fra Jean Anker og Svend Dabl, Fabeldyr og andre fabelvæsener, 1938.

har fungeret som en model for begrebet erhvervet immunologisk tolerance, altså det fænomen, at to individer med forskellig vævstype, som tidligt i tilværelsen havde blandet blod og celler, hele livet igennem ville kunne tåle transplantation med hinandens væv, uden at afstøde dette.

En hermafrodit er betegnelsen for et væsen - f.eks. en plante eller et dyr - der har både han- og hunkønsorganer. Dersom organismen er frugtbar - i stand til at formere sig med begge køn - er den tvekønnet. Ordet stam-

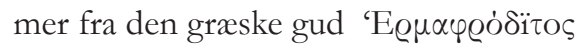
(Hermaphroditos), som var søn af Hermes og Aphrodite. Hermaphroditos er ofte afbildet som en vinget yngling med kvindeligt rundede lår, bryster og kvindefrisure, samt mandlige genitalier.

Foto: Inga Bára Ragnarsdottir, Rie Dunvad og Lis Milo Diemer. 